Budi Aspani, Eksistensi Peradilan Tata Usaha Negara Dalam Penyelenggaraan Pemerintahan, halaman 114-121

\title{
EKSISTENSI PERADILAN TATA USAHA NEGARA DALAM PENYELENGGARAAN PEMERINTAHAN
}

\author{
Budi Aspani \\ Fakultas hukum Universitas Palembang \\ e-mail: budiaspani@yahoo.com
}

\begin{abstract}
Legal protection of citizens for acts committed by the authorities can be done through 3 (three) bodies, namely the State Administration Agency, through administrative efforts, the State Administrative Court, based on Undag - Law Number 5 of 1986, General Judiciary, through Article 1365 of the Civil Code. In an effort to approach the main problem in this study, the authors use the type of library research that is descriptive analysis, namely by conducting research on library materials, then carried out an analysis by referring to the laws and regulations in the fields related to the problem under study. After discussing the existing problems, it can be concluded that the authority or competence of the State Administrative Court Judge is to examine, decide upon and resolve the State Administration dispute between civil persons or legal entities as a result of the issuance of a State Administration Decree. The State Administration Decree issued by the State Administration Agency / Officer can be denied by submitting Administrative Efforts consisting of Administrative Objections and Appeals. Against Decisions Administrative efforts in the form of administrative objections and appeals can be filed with the State Administrative Court within a grace period of 90 (ninety) days from the date of receipt or announcement of the Decree of the State Administration Agency / Officer.
\end{abstract}

Keywords: Existence; State Administrative Court; Government

\section{ABSTRAK}

Perlindungan hukum terhadap warga masyarakat atas perbuatan yang dilakukan oleh penguasa dapat dilakukan melalui 3 (tiga) badan, yitu Badan Tata Usaha Negara, dengan melalui upaya administratif, Peradilan Tata Usaha Negara, berdasarkan Undag - Undang Nomor 5 Tahun 1986, Peradilan Umum, melalui Pasal 1365 KUHPerdata. Dalam usaha mendekati pokok permasalahan dalam penelitian ini, penulis menggunakan tipe penelitian kepuustakaan yang bersifat deskriftip analisis, yaitu dengan melakukan penelitian terhadap bahan-bahan kepustakaan, selanjutnya dilakukan analisa dengan mempedomani peraturan-peraturan perundang-undangan di bidang yang terkait dengan masalah yang diteliti. Setelah melakukan pembahasan terhadap permasalah yang ada, maka dapat diperoleh kesimpulan bahwa Kewenangan atau kompetensi Hakim Peradilan Tata Usaha Negara adalah untuk memeriksa, memutus dan menyelesaikan sengketa Tata Usaha Negara antara orang atau badan hukum perdata sebagi akibat dikeluarkannya Keputusan Tata Usaha Negara. Keputusan Tata Usaha Negara yang dikeluarkan oleh Badan/Pejabat Tata Usaha Negara tersebut dapat disangkal dengan cara mengajukan Upaya Administratitif yang terdiri dari Keberatan dan Banding Administratif. Terhadap Keputusan Upaya administratif berupa keberatan dan banding administrasi dapat diajukan gugatan ke Pengadilan Tata Usaha Negara dalam tenggang waktu selama 90 (sembilan puluh) hari terhitung sejak saat diterima atau diumumkannya Keputusan Badan/Pejabat Tata Usaha Negara Tesebut.

\section{Kata Kunci: Eksistensi; Peradilan Tata Usaha Negara; Pemerintahan}

\section{PENDAHULUAN}

\section{A. Latar Belakang}

Negara Indonesia adalah Negara Hukum. ${ }^{1}$ Negara Hukum menghendaki segala tindakan atau perbuatan waraga maupun penguasa mempunyai dasar hukum yang jelas atau ada legalitasnya baik berdasarkan hukum tertulis maupun hukum yang tidak tertulis.

Keabasahan negara memerintah ada yang mengatakan bahwa karena negara merupakan lembaga yang netral tidak

\footnotetext{
1 Amandemen Undang-Undang Dasar 1945, New Merah Putih, Yogyakarta, 2009, \Halaman 10
}

memihak, berdiri di atas kepentingan semua golongan masyarakat, dan mengabdi kepada kepentingan umum. ${ }^{2}$ Namun di dalam praktek tidak jarang istilah - istilah " demi kepentingan umum ", “ Pembangunan untuk masyarakat ", serta ungkapan lain yang senada selalu memandang dalam pernyataan pernyataan politik para petinggi negara, dapat saja dipakai sebagai pembenaran terhadap pengguna kekuasaan negara untuk memaksa

\footnotetext{
${ }^{2}$ Arif Budiman, Teori Negara ; Negara, Kekuasaan dan Ideologi, PT. Gramedia Pustaka Utama, Jakarta, 1996, Halaman 1
} 
Budi Aspani, Eksistensi Peradilan Tata Usaha Negara Dalam Penyelenggaraan Pemerintahan,

halaman 114-121

seseorang atau sekelompok warga agar bersedia mematuhi keinginan negara. ${ }^{3}$

Negara Hukum pada dasarnya terutama bertujuan untuk memberikan perlindungan hukum bagi rakyat. Menurut Philipus M. Hadjon, bahwa perlindungan hukum bagi rakyat terhadap tindakan pemerintah dilandasi oleh dua prinsip yaitu prinsip hak asasi manusia dan prinsip negara hukum. Pengakuan dan perlindungan terhadap hak asasi manusia mendapat tempat utama dan dapat dikatakan sebagai tujuan dari pada negara hukum. Sebaliknya dalam negara otoriter tidak ada tempat bagi hak asasi manusia. $^{4}$

Konsep negara hukum lahir dari suatu perjuangan menentang absolutisme sehingga sifatnya dapat kikatakan sangat revolusioner. Salah satu contoh pada zan Romawi kekuasaan yang menionjol dari raja ialah membuat peraturan melalui Dekrit. Kekuasaan ini kemudia didelegasikan kepada pejabat - pejabat administratif, sehingga pejabat - pejabat adminitratif yang membuat pengarahan - pengarahan tertulis bagi hakim tentang bagaimana memutus suatu sengketa. Begitu besarnya peranan administratif negara, sehingga tidaklah mengherankan adanya hubungan antara pejabat administratif negara dengan rakyat, dan perkembangannya peranan administasi negara bertambah luas. Oleh karena hal inilah patut dipikirkan langkah - lamgkah untuk membatasi kekuasaan administrasi dari pada negara.

Dasar peradilan dalam UndangUndang Dasar 1945 dapat ditemukan dalam pasal 24 yang menyebutkan bahwa :

(1) Kekuasaan kehakiman merupakan kekuasaan yang merdeka untuk menyelenggarakan peradilan guna menegakkan hukum dan keadilan.

(2) Kekuasaan kehakiman dilakukan oleh sebuah Mahkamah Agung dan badan peradilan yang berada di bawahnya dalam lingkungan peradilan umum, lingkungan peradilan agama, lingkungan peradilan militer, lingkungan peradilan

\footnotetext{
${ }^{3}$ Ibid., Halaman 1-2

${ }^{4}$ Philips M. Hadjon, Perlindungan Hukum Bagi Rakyat di Indonesia, PT. Bina Aksara, Surabaya, 1987, Halaman 71
}

tata usaha negara, dan oleh sebuah Mahkmah Konstitusi.

(3) Badan-badan lain yang fungsinya berkaitan dengan kekuasaan kehakiman diatur dalam undang-undang.

Sebagai pelaksanaan Pasal 24 Undang-Undang Dasar 1945, dikeluarkan Undang-Undang Nomor 14 Tahun 1970 dan telah diganti oleh Undang_undang Nomor 4 Tahun 2004 Tentang Kekuasaan Kehakiman. Di dalam Pasal 10 Undang-Undang Nomor 4 Tathun 2004 di atas disebutkan bahwa :

(1) Kekuasaan kehakiman dilakukan oleh sebuah Mahkamah Agung dan badan peradilan yang berada di bawahnya, dan oleh sebuah Mahkamah Konstitusi.

(2) Badan peradilan yang berada di bawah Mahkamah Agung meliputi badan peradilan dalam lingkungan peradilan umum, peradilan agama, peradilan militer, dan peradilan taa usaha negara.

Dengan demikian penyelenggaraan peradilan tata usaha negara (peradilan administrasi) di Indonesia merupakan suatu kehendak konstitusi dalam rangka memberikan perlindungan hukum terhadap rakyat secara maksimal. Dengan diberlakukannya Undang-Undang Nomor 5 Tahun 1986 Tentang Peradilan Tata Usaha Negara yang berdasarkan Pasal 144 dapat disebut Undang-Undang Peradilan Administrasi Negara, maka dewasa ini perlindungan hukum terhadap warga masyarakat atas perbuatan yang dilakukan oleh pengusasa dapat dilakukan melalui 3 (tiga) badan, yakni sebagai berikut $:^{5}$

a. Badan Tata Usaha Negara, dengan melalui upaya administratif.

b. Peradilan Tata Usaha Negara, berdasarkan Undag - Undang Nomor 5 Tahun 1986.

c. Peradilan Umum, melalui Pasal 1365 KUHPerdata .

Dalam kenyataannya, dapat kita rasakan akhir-akhir ini perkembanganperkembangan dari berbagai macam permasalahan yang muncul kepermukaan merupakan salah satu sebab tindakan para

\footnotetext{
${ }^{5}$ Soerjono, Perbuatan Melawan Hukum Yang Dilakukan Oleh Penguasa dan Masalah Ganti Rugi,Dalam MA, Himpunan Karangan di Bidang Tata Usaha Negara, Jakarta, Halaman 41
} 
Budi Aspani, Eksistensi Peradilan Tata Usaha Negara Dalam Penyelenggaraan Pemerintahan, halaman 114-121

penguasa yang telah menimbulkan kerugian terhadap seseorang atau badan hukum perdata, diantaranya pegawai negeri yang dijatuhi salah satu jenis hukuman disiplin melalui Badan Pertimbangan Kepegawaian (BAPEK).

\section{B. Perumusan Masalah}

Permasalahan penulisan ini adalah :

1. Apa langkah-langkah yang dapat ditempuh dalam melakukan Upaya Administratif ?

2. Sejauh manakah Tenggang waktu dalam mengajukan gugatan di Pengadilan Tata Usaha Negara?

\section{Metodologi Penelitian}

1. Spesifikasi Penelitian.

Dalam usaha mendekati pokok permasalahan dalam penelitian ini, penulis menggunakan tipe penelitian kepuustakaan yang bersifat deskriftip analisis, yaitu dengan melakukan penelitian terhadap bahan-bahan kepustakaan, selanjutnya dilakukan analisa dengan mempedomani peraturanperaturan perundang-undangan di bidang yang terjait dengan masalah yang diteliti.

2. Pendekatan Penelitian.

Penelitian ini menggunakan pendekatan yuridis normatif. Artinya penelitian sepenuhnya menggunakan data sekunder, maka penyusunannya tidak diperlukan merumuskan hipotesa.

3. Sumber Data.

Karena penelitian ini bersifat yuridis normatif, maka untuk memperoleh hasil penelitian, data yang diperlukan adalah data seknder. Dalam penelitian hukum, data sekunder dari sudut kekuatan mengikatnya dapat dibedakan kedalam (i) bahan hukum primer seperti peraturan perundang-undangan yang bersifat mengikat (ii) bahan hukum sekunder yang membrikan penjelasan mengenai bahan hukum primer seperti rancangan undang-undang, hasil pnrlitisn, penelitian, hasil karya ilmiah dari kalangan hukum dan sebagainya, serta (iii) bahan hukum tersier yaitu bahan hukum yang memberikan petunjuk maupun penjelasan terhadap bahan hukum primer dan sekunder, contohnya kamus, ensiklopedia dan sebagainya.

\section{PEMBAHASAN}

A. Kompetensi Pengadilan

Kompetensi menurut Kamus Besar Bahasa Indonesia adalah kewenangan (kekuasaan) untuk menentukan (memutuskan sesuatu). ${ }^{6}$ Kompetensi (kekuasaan) dari suatu pengadilan untuk memeriksa, mengadili dan memutuskan suatu perkara berkaitan dengan jenis dan tingkatan pengadilan yang ada berdasarkan peraturan perundang-undangan yang berlaku.

Sebagaimana diketahui bahwa berdasarkan jenisnya, lingkungan pengadilan dibedakan atas pengadilan umum, pengadilan militer, pengadilan agama, dan pengadilan tata usaha negara (pengadilan administrasi). Sedangkan berdasarkan tingkatannya pengadilan itu terdiri atas pengadilan tingkat pertama, pengadilan tionggi (pengadilan tingkat banding) Mahkamah Agung (pengadilan kasasi) dan sebuah Mahkamah konstitusi.

Kedudukan dan jenis tingkat dari pengadilan tersebut adalah pengadilan tingkat pertama yang berkedudukan disetiap Kabupaten/Kota, pengadilan tinggi (banding) berkedudukan di setiap provinsi dan Mahkamah Agung (kasasi) sebagai puncak dari semua lingkungan peradilan yang ada., serta Mahkamah Konstitusi (tingkat pertama dan terakhir) berkedudukan di Ibu Kota Negara.

Pembentukan PTUN dan PT TUN ini dilakukan secara bertahap, karena memerlukan perencanaan dan persiapan yang sebaik-baiknya, baik yang menyangkut masalah teknis maupun non teknis. Untuk itu dalam Pasal 145 UU No. 5 Tahun 1986 disebutkan bahwa Undang-Undang PTUN di tunda perberlakuaanya selambat-lambatnya 5 (lima) tahun sejak diundangkannya. Maka untuk pertamakalinya dibentuk PTUN di Jakarta, Medan, Palembang, Surabaya dan Ujung Pandang berdasarkan Keputusan

${ }^{6}$ Zairin Harahap, Hukum Acara Peradilan Tata Usaha Negara, PT.Raja Persada, Jakarta,1977, Halaman 29 
Budi Aspani, Eksistensi Peradilan Tata Usaha Negara Dalam Penyelenggaraan Pemerintahan, halaman 114-121

Prasiden/Kepres No. 52 Tahun 1990. ${ }^{7}$, mengadili dan memutuskan suatu perkara : Pertama dapat dilihat dari pokok sengketa (fundamental punendi) ${ }^{8}$, kedua, dengan melakukan atas atribusi (absolit comptentie) dan delegasi (relatife competentie) ${ }^{9}$, ketiga, dengan melakukan pembedaan atas kompetensi absolut dan kompetensi relatif. Dapat dilihat dari pokok sengketanya, apabila pokok sengketanya terletak dalam lapangan hukum privat, maka sudah tentu yang berkompetensi adalah hakim biasa (hakim dari pengadilan umum). Apabila pokok sengketanya terletak dalam hukum publik, maka sudah tentu yang berkompetensi adalah administrasi yang berkuasa (hakiim PTUN), cara ini tampaknya sudah kurang memadai untuk menjelaskan secara lengkap kompetensi suatu pengadilan sebagaimana yang diuraikan diatas. Timbul pertanyaan sekarang apakah Keputusan Tata Usaha (KTUN) merupakan kewenangan hakim Peradilan Tata Usaha Negara di dalam hal adanya upaya administratif menurut ketentuan Pasal 48 UU No. 5 Tahun 1986 ?

Untuk menjawab pertanyaan di atas, maka pembahasan akan diketengahkan pada uraian di bawah ini.

\section{B. Langkah - Langkah Yang Ditempuh Dalam Upaya Administratif}

Pasal 48 Ayat (1 dan 2) menyebutkan :

(1) Dalam hal suatu Badan atau Pejabat Tata Usaha Negara diberi wewenang oleh atau berdasarkan peraturan prundang-undangan untuk menyelesaikan secara administrattif sengketa Tata Usaha Negara tertentu, maka sengketa Tata Usaha Negara tersebut harus diselesaikan melelui upaya administratif yang tersedia;

(2) Pengadilan baru berwenang memeriksa, memutus, dan menyelesaikan sengketa Tata Usaha Negara sebagaimana dimaksud dalam Ayat (1) jika seluruh

\footnotetext{
${ }^{7}$ Ibid., Halaman 30

8 E. Utrecht, Pengantar Hukum Administrasi Indonesia, Tinta Mas, Surabaya, 1986, Halaman 252

${ }^{9}$ Sjahran Basah, Eksistensi dan Tolak Ukur Badan Peradilan Administrasi di Indonesia, Alumni Bandung, 1990, Halaman 68-69
}

upaya administratif yang bersangkutan telah digunakan.

Pasal 55 Undang-Undang Nomor 5 Tahun 1986, menyebutkan :

"Gugatan dapat diajukan hanya dalam tenggang waktu sembilan puluh hari terhitung sejak diterimanya atau diumumkannya Keputusan Badan atau Pejabat Tata Usaha Negara".

Setelah dipahami dengan benar tentang ciri-ciri dari hukum acara TUN yang berbeda dengan yang berlaku dalam proses perdata serta siapa-siapa saja yang dapat menjadi pihak-pihak dalam suatu proses di muka Pengadilan Tata Usaha Negara (PTUN), kama sebelum seorang calon penggugat mengajukan surat gugatannya yang seluruh ia harus pertama-tama perlu memperhatikan :

a. Pasal 48 teersebut yang menentukan bahwa pengadilan berwenang memeriksa, memutus dan meyelesaikan sengketa tata usaha negara jika seluruh upay administratif yang bersangkutan telah digunakan, dan

b. Pasal 55 yang mengharuskan, bahwa gugatan tata usaha negara hanya dapat diajukan dalam tenggang waktu 90 hari terhitung sejak saat diterimanya atau diumumkannya keputusan Badan atau Pejabat Tata Usaha Negara yang digugat.

Seperti yang dikatakan dalam penjelasan undang-undang No. 5 Tahun 1986 di atas, maka upaya administratif itu merupakan prosedur yang ditentukan dalam suatu peraturan perundang-undangan untuk menyelesaikan suatu sengketa TUN yang dilaksanakan dilingkungan pemerintahan itu sendiri (Bukan Oleh badan peradilan yang bebas) yang terdiri dari :

a. Prosedur keberatan, dan

b. Prosedur banding administratif

Dalam praktek adanya prosedur upaya administratif itu kadangkala tidak begitu saha dengan mudah dapat seketika diketemukan dalam peraturan saahari-hari yang kita baca, contohnya upaya administratif terhadap keputusan IMB (Izin Mendirikan Bangunan), karena peraturan dasarnya masih berasal dari dan terdapat dalam peraturan zaman kolonial, sedangkan perda-perda yang kita baca dan kita anggap merupakan peraturan kelanjutan 
Budi Aspani, Eksistensi Peradilan Tata Usaha Negara Dalam Penyelenggaraan Pemerintahan, halaman 114-121

tidak menyebutkan sama sekali. Karena itu dari para hakim Tata Usaha Negara duharapkan ketelitian dan keseksamaan dalam menelusuri peraturan dasar dari setiap keputusan Tata Usaha Negara (TUN) yang disengketakan.

Berkenaan dengan uraian di atas, Zairin Harahap mengemukakan, bahwa upaya administratif itu merupakan prosedur yang ditentukan dalam suatu peraturan perundangundangan untuk menyelesaikan sengketa TUN yang dilaksanakan dilingkungan pemerintahan sendiri (bukan oleh peradilan yang bebas) yang terdiri dari prosedur keberatan dan prosedur banding administratif. ${ }^{10}$

Dalam Penjelasan Pasal 48 disebutkan bahwa upaya administratif adalah suatu perosedur yang dapat ditempuh oleh seseorang atau badan hukum perdata apabila ia tidak puas terhadap suatu keputusan Tata Usaha Negara. Prosedur itu dilaksanakan dilingkungan pemerintahan sendiri. Dalam hal penyelesaiannya itu dilakukan oleh instansi atasan atau instansi lain dari yang mengeluarkan keputusan yang bersangkutan, maka prosedur tersebut dinamakan prosedur banding administratif. Dalam hal penyelesaiannya KTN ( Keputusan Tata Usaha Negara) tersebut harus dilakukan sendiri oleh badan atau pejabat tata usaha negara yang mengeluarkan keputusan itu, maka prosedur yang ditempuh tersebut disebut Keberatan.

$\begin{array}{rccc}\text { Dalam } & \text { Bab IV tentang } \begin{array}{r}\text { Upaya } \\ \text { Administratif }\end{array} \text { (Pasal } 48 \text { berserta }\end{array}$
Penjelasannya), angka 2 Hurup a dan b dari surat Edaran Mahkamah Agung Nomor 2 Tahun 1991 tentang Petunjuk Pelaksanaan Beberapa ketentuan dalam Undang-Undang Nomor 5 Tahun 1986 tentang Peradilan Tata Usaha Negara menyebutkan : ${ }^{11}$

a. Apabila peraturan dasarnya hanya menentukan adanya upaya administraif berupa pengajuan keberatan, maka gugatan terhadap KTUN yang bersangkutan diajukan kepada TUN.

\footnotetext{
${ }^{10}$ Zairin Harahap, Op.Cit, Halaman 76

${ }^{11}$ Ibid., Halaman 78
}

b. Apabila peraturan dasarnya menentukan adanya upaya administratif berupa pengajuan surat keberatan dan atau mewajibkan pengajuan surat banding administratif, maka gugatan terhadap keputusan TUN yang telah diputus dalam tingkat banding administratif diajukan langsung kepada PT TUN dalam tingkat pertama yang berwenang.

Dengan demikian ketentuan Pasal 51 Ayat (3) yang menyebutkan bahwa PTUN bertugas dan berwenang memeriksa dan memutus, dan menyelesaikan di tingkat pertama sengketa Tata Usaha Negara sebagaimana dimasud dalam Pasal 48 apabila sdengketa itu telah diputus dalam tingkat banding adminitratif, sedangkan apabila upaya administratif yang tersedia hanya berupa keberatan, maka gugatan KTUN yang di putus dalam tingkat upaya keberatan tersebut tidak dapat diajukan langsung kepada PT TUN, tetapi kepada Pengadilan Tata Usaha Negara (PTUN).

Perbedaan penting antara upaya administratif dan PTUN (Pengadilan Tata Usaha Negara) bahwa PTUN hanyalah memeriksa, dan menilai dari segi hukumnya saja. Sedangkan penillaian dari segi kebijaksanaan bukan melalui atau bukan menjadi wewenang PTUN. Pemeriksaan upaya administratitf, badan TUN selain berwenang menilai segi hukumnya, juga berwenang menilai segi kebijaksanaannya. Dengan demikian penyelesaian melalui upaya administratif menjadi lengkap. ${ }^{12}$ Tetapi penilaian secara lengkap tersebut tidak termasuk pada prosedur banding. Pada prosedur banding, badan TUN hanya melakukan penilaian dari segi hukumnya saja. $^{13}$

Tersedia atau tidaknya upaya administratif terhadap suatu Kepuutusan TUN ditentukan oleh suatu peraturan perundangundangan. Keberatan atau pengaduan yang

\footnotetext{
${ }^{12}$ Ibid., Halaman 78

${ }^{13}$ Soerjono Soekanto, Perbuatan Melanggar Hukum Oleh Penguasa dan Masalah Ganti Rugi, Himpunan Karangan di bidang hukum TUN, PPTH dan Hukum MA, Jakarta, 1993, Halaman 42
} 
Budi Aspani, Eksistensi Peradilan Tata Usaha Negara Dalam Penyelenggaraan Pemerintahan, halaman 114-121

tidak ada dasar hukumnya, tidak dapat disebut sebagai upaya untuk menyelesaikan sengketa TUN melalui Upaya Administratif. Beberapa perundang-undangan yang memuat upaya administratif adalah UU No. 6 /1983 untuk penyelesaian yang menyangkut wajib pajak, PP 30/1980 untuk menyelesaikan sengketa kepegawaian, P4D (Panitia Penyelesaian Perselisihan Perburuhan Daerah), P4P (Panitia Penyelesaian Perselisihan Perburuhan Pusat) untuk perselisihan perburuhan.

C. Tenggang Waktu Mengajukan Gugatan

Dalam hukum acara TUN pengajuan gugatan dapat dilakukan hanya dalam tenggang waktu 90 hari (sembilan puluh) hari, yang dihitungsejak saat diterimanya atau diumumkannya Keputusan TUN. Hal ini berarti apabila gugatan tersebut diajukan setelah lewat 90 (sembilan puluh)hari, maka pengadilan tidak akan menerima gugatan. Oleh karena itu harus pandai-pandai menghitung batas waktu terebut, karena kewat dari batas waktu tersebut gugatan akan ditolak oleh pengadilan.

Kesulitan yang akan muncul adalah apabila tenggang waktu mengajukan gugatan itu dikaitkan dengan Pasal 3 UU No. 5 Tahun 1986, yakni terhadap keputusan TUN yang bersifat negatif. Sepintas Keputusan TUN negatif memberikan perlindungan hukum terhadap masyarakat tentang kepastian hukum tehadap haknya. Namun apabila ditelusuri lebih jauh dikaitkan dengan ketentuan tenggang waktu, maka tidak semua orang tahun apakah suatu peraturan perundangndangan ,memuat tegas tentang tenggang waktu mengeluarkan KTUN. Sekalpun dalam Pasal 3 Undang-Undang Peradilan Tata Usaha Negara (PTUN) itu disebutkan bahwa apabila peraturan perundang-undangan yang bersangkutan tidak nengaturnya, maka dengan tenggang waktu adalah 4 (empat) bulan, terhitung sejak permohonan Keputusan Tata Usaha Negara itu diajukan. Dalam kondisi masyarakat masyarakat yang serta menerima dan sangat berpraangka baik terhadap pejabat, sehingga selalu sabar mengunggu. Dengan demikian, siapa yang dapat menjamim bahwa ketentuan tenggang waktu mengajukan gugatan tidak daluarsa.

Dalam Pasal 3 UU PTUN tersebut, tampaknya menyadari sepenuhnya kondisi peraturan perundang-undangan yang ada pada saat UU PTUN ini diundangkan, sehingga memara perlu memasukan ketentuan peralihan mengenai tenggang waktu mengajukan gugatan tersebut. Oleh karenanya untuk memberikan perlindungan hukum secara maksimal kepada masyarakat, sudah semestinya peraturan perundangundangan yang belum mengatur tentang tenggang waktu mengeluarkan Kputusan TUN agar segera mengaturnya.

Dalam hukum acara perdata, tenggang waktu mengajukan gugatan yang mengakibatkan gugatan menjadi daluarsa atau prematur tidakloah begitu prinsif dibandingkan dengan hukum acara PTUN sebagaimana dapat dijelskan di atas. Dalam hukum acara perdata, memang dapat saja terjadi gugatan dianggap daluarsa, tetapi kadaluarsanya gugatan itu semata-mata karena kelalaian penggugat. Berbeda dengan hukum acara PTUN, daluarsanya gugatan dapat digugat dapat dikatakan semata-mata ketidak tahuan penggugat. Disamping itu dalam hukum perdata tenggang waktu mengajukan gugatan relatif lebih lama dan berbeda tenggang waktunya. Begitu juga mengenai gugatan prematur menjadi sangat naif, karena penggugat seharusnya mengetahui bahwa tergugat belum dapat dikatakan wanprestasi sebelum tenggang waktu yang diperjanjikan jatuh tempo.

Berbeda dengan Indro Harto, yang menyatakan bahwa setelah sweorang calon penggugat itu merasa pasti, bahwa untuk menggugat keputusan TUN yang dirasakannya merugikan itu menurut peraturan dasarnya tidak tersedia suatu upaya administratif yang harus ditempuh terlebih dahulu atau upaya administratif itu sudah ia tempuh tetapi hasilnya tidak memuaskan baginnya, maka ia harus menghitung-hitung apakah gugatan yang akan ia ajukan itu masih berada dalam tenggang waktu 90 hari sebagaimana ditentukan dalam pasal $55 \mathrm{UU}$ No. 5 Tahun 1986.

Ketentuan mengenai tenggang waktu 90 hari itu tidak ada ketentuan pengscualiannya, artinya selalu dihitung sejak diterimanya keputusan Badan atau Jabatan YUN yang akan digugat. Hal ini berarti juga berlaku bagi pengajuan gugatan yang 
Budi Aspani, Eksistensi Peradilan Tata Usaha Negara Dalam Penyelenggaraan Pemerintahan, halaman 114-121

diajukan terhadap Keputusan TUN yang dikeluarkan dalam rangka upaya keberatan atau peleksanaan pengawasan administratif yang bersifat preventif maupun refresif serta terhadap Keputrusan Tata Usaha Negara yang dikeluarkan dalam rangka upaya keberatan dan banding administratif. Jadi apabila yang hendak digugat itu Keputusan Tata Usaha Negara tersebut terhadapnya terbuka suatu upaya administratif maka dalam tenggang waktu 90 hari untuk mengajukan gugatan itu harus dihitung sejak hari diterimanya atau diumumkannya Keputusan Tata Usaha Negara yang dikeluarkan oleh Badan atau Jabatan TUN yang mengenai / memutuskan uapaya administratif yang bersangkutan, maka tenggang waktu 90 hari tersebut seudah dapat dihitung sejak diterimanya atau diumumkannya Keputusan Tata Usaha Negara semula.

Ketentuan Pasal 48 itu metupakan ketentuan imperatif sifatnya, artinya kelau yang tersedia itu dan macam prosedur (prosedur keberatan maupun peosedur banding administratifo maka kedua macam prosedur itu harus ditempuh lebih dahulu sebelum mengajukan gugatan ke Pengadilan Tata Usaha Negara.

Jika kita perhatikan, mungkin sekali dalam peraturan dasarnya hanya tersedia suatu macam prosedur (Prosedur keberatan atau prosedur banding administratif saja), maka setelah prosedur yang tersedia itu ditempuh barulah penggugat dapat kemgajukan ke Pengadilan Tata Usaha Negara. Sekarang persoalannya adalah, dalam kongkretonya mulai saat kapan tenggang waktu 90 hari itu harus dihitung ? Mengenai hal ini perlu menjabarkan pengertian “ diterimanya atau diumumkannya Keputusan Tata Usaha Negara yang hendak digugat tersebut.

Indroharto memandang masalah tenggang waktu untuk mengajukan gugatan ini tidak perlu dibedakan antara yang berlaku bagi penggugat sebagai alamat yang dituju dengan penggugat sebagai pihak ketiga yang berkepentingan. Artinya, apabila pihak ketiga yang berkepentingan itu hendak mengajukan gugatan sendiri (bukan melakukan suatu intervensi kedalam suatu proses yang sedang berjalan), maka ketentuan-ketentuan mengenai tenggang waktu mengajukan gugatan yang berlaku bagi penggugat pada umumnya juga berlaku baginya. ${ }^{14}$

Lebih lanjut dikatakan, artinya ; karena pihak ketiga itu bukan berkedudukan sebagai alamat yang dituju oleh keputusan TUN yang bersangkutan maka tenggang waktu untuk mengajukan gugatan harus ia ikuti tenggang waktu bagi alamat yang dituju. Dalam SEMA No. 2 Tahun 1991 Tanggal 3 Juli tersebut diadakan penghalusan mengenai tenggang waktu ini khusus yang berlaku bagi pihak ketiga (bukan si alamat yang dituju) sebagai berikiut :

"Bagi mereka yang tidak dituju oleh suatu keputusan TUN, tetapi yang merasa kepentinngannya dirugikan maka tenggang waktu sebagaimana dimaksud dalam Pasal 55 dihitung secara kasuistis sejak saat ia merasa kepentingannya dirugikan oleh keputusan TUN yang bersangkutan dan mengetahui adanya keputusan TUN yang bersangkutan ". 15

Penghalusan ini menurut Indoharto, dimaksudkan untuk lebih memenuhi rasa keadilan yang berupa kesempatan untuk menggunakan bagi pihak ketiga bukan alamat yang dituju. Namun apabila hal ini dilakukan terlalu jauh dan terlalu sering diterapkan akan berakibat prinsip utama UU bahwa Peradilan ini diadakan hanya melihat kedepan. Jadi pada prinsipnya UU lebih mementingkan stabilitas pemerintahan dari pada kepentingan perseorangan.

Kesalah tindakan-tindakan pemerintahan yang sudah dan dan sudah mapan dalam masyarakat memang tidak dibenarkan untuk diganggu gugat lagi lewat peradilan tata usaha negara. Yang sering menyulitkan bagi Hakim TUN adalah, kelau menghadapi penggugat pihak ketiga yang tidak jujur, formal dalam gugatannya ia tulis, bahwa sewaktu ia menerima atau mendengar tentang adanya keputusan yang ia sengketakan itu masih dalam tenggang waktu 90 hari. Padahal keputusannya sendiri sudah

\footnotetext{
${ }^{14}$ Ibid., Halaman 56

${ }^{15}$ SEMA No. 2 Tahun 1991, Tentang Petunjuk Pelaksanaan Beberapa Ketentuan Dalam UU No. 5 Tahun 1986 Tentang Peradilan TUN, 1991, Halaman 302
}

Volume 17 Nomor 2. Bulan Mei 2019 
Budi Aspani, Eksistensi Peradilan Tata Usaha Negara Dalam Penyelenggaraan Pemerintahan, halaman 114-121

dikeluarkan beberapa tahun sebelumnya atau kalau mengenai surat-surat tanah, tanahnya sendiri sudah berulangkali berpindah tangan melalui prosedur yang wajar. Diantara para hakim TUN ada yang berpegang pada tanggal yang disebut oleh Penggugat dalam surat gugatannya, tanpa meneliti lebih lanjut langsung menerima gugatan semacam itu untuk diproses.

Dalam menghadapi dalil yang meragukan demikian itu hakim harus lebih bujaksana dengan meneliti lebih dalam kebenaran dalil penggugat tersebut. Timbul pertanyaan bagi kita mengapa setelah sekian tahun penggugat baru sekarang menerima atau mendengar tentang adanya pengumuman tersebut ? Untuk mdenjawab pertanyaan ini, dapat dikemukakan bahwa paling tidak penggugat harus membuktikan lebih dahulu keadaan-keadaan yang menunjukkan dimana ia berada waktu itu sehingga ia dalam keadaan yang tidak mungkin dapat menerima datau mendengar tentang adanya keputusan yang baru sekarang ini ia gugat. Dalam halhal yang demikian pada prinsipnya yang dimungkinkan hanyalah gugatan untuk menuntut ganti rugi ke Peradilam Perdata yang tidak membawa akibat harus dibatalkan atau dinyatakan tidak syahnya suatu keputusan yang telah lama keluar tersebut.

\section{KESIMPULAN}

Dapat disimpulkan bahwa :

1. Kewenangan atau kompetensi Hakim Peradilan Tata Usaha Negara adalah untuk memeriksa, memutus dan menyelesaikan sengketa Tata Usaha Negara antara orang atau badan hukum perdata sebagi akibat dikeluarkannya Keputusan Tata Usaha Negara.

2. Keputusan Tata Usaha Negara yang dikeluarkan oleh Badan/Pejabat Tata Usaha Negara tersebut dapat disangkal dengan cara mengajukan Upaya Administratitif yang terdiri dari :

a. Keberatan, dan

b. Banding Administratif.

3. Terhadap Keputusan Upaya administratif berupa keberatan dan banding administrasi dapat diajukan gugatan ke Pengadilan Tata Usaha Negara dalam tenggang waktu selama 90 (sembilan puluh) hari terhitung sejak saat diterima atau diumumkannya Keputusan Badan/Pejabat Tata Usaha Negara Tesebut.

\section{DAFTAR BACAAN}

Amandemen Undang-Undang Dasar 1945, New Merah Putih, Yogyakarta, 2009,

Arif Budiman, Teori Negara ; Negara, Kekuasaan dan Ideologi, PT. Gramedia Pustaka Utama, Jakarta, 1996,

E. Utrecht, Pengantar Hukum Administrasi Indonesia, Tinta Mas, Surabaya, 1986

Indiharto, Usaha Memahami UU tentang Peradilan Tata Usaha Negara, Pustaka Sinar Harapan, Jakarta, 1996

Philips M. Hadjon, Perlindungan Hukum Bagi Rakyat di Indonesia, PT. Bina Aksara, Surabaya, 1987

SEMA No. 2 Tahun 1991, Tentang Petunjuk Pelaksanaan Beberapa Ketentuan Dalam UU No. 5 Tahun 1986 Tentang Peradilan TUN, 1991

Sjahran Basah, Eksistensi dan Tolak Ukur Badan Peradilan Administrasi di Indonesia, Alumni Bandung, 1990

Soegijatno Tjakranegara, Hukum Acara Peradilan Tata Usaha Negara Di Indonesia, Sinar Grafika, Jakarta, 1992

Soerjono Soekanto, Perbuatan Melanggar Hukum Oleh Penguasa dan Masalah Ganti Rugi, Himpunan Karangan di bidang hukum TUN, PPTH dan Hukum MA, Jakarta, 1993

Zairin Harahap, Hukum Acara Peradilan Tata Usaha Negara, PT. Raja Grafindo Persada, Jakarta, 1997 